\title{
Toxicity and genotoxicity studies of surface and waste water samples using a bacterial SOS/umu test and mammalian MTT and comet assay
}

\author{
B. Žegura ${ }^{1}$, E. Heath ${ }^{2}$, A. Černoša ${ }^{3}$ \& M. Filipič ${ }^{1}$ \\ ${ }^{1}$ National Institute of Biology Department of Genetic Toxicology and \\ Cancer Biology, Ljubljana, Slovenia \\ ${ }^{2} J$ žef Stefan Institute, Department of Environmental Sciences, Ljubljana, \\ Slovenia \\ ${ }^{3}$ University of Ljubljana, Faculty of Pharmacy, Ljubljana, Slovenia
}

\begin{abstract}
Surface and waste waters are complex mixtures that may contain thousands of different pollutants of different origins (industrial, agricultural and domestic). Many of them show toxic and/or genotoxic effects and are therefore potentially hazardous for humans and the environment.

It is extremely difficult to quantify the risk associated with xenobiotics in environmental samples because they usually occur in concentrations too low to allow chemical analytical determination. Additionally, single and combined biological effects of most of the micropollutants are not known. The best approach to evaluate potential toxic/genotoxic risks of such mixtures is to use biological test systems with living cells or organisms that give a global response to the pool of micropollutants present in the sample.

In this study we evaluated the cytotoxic/genotoxic potential of 51 different water samples (river, potable, well, lake, and waste waters) potentially contaminated with pharmaceutical and personal care products (PPCP). The samples were evaluated for their genotoxic potential with the bacterial SOS/umu test with Salmonella typhimurium TA1535/pSK1002 and for their cytotoxic potential with mammalian cell based MTT assay with human hepatoma (HepG2) cells. Genotoxicity of seven selected samples was further tested with the comet assay with metabolically competent HepG2 cells.

The results from the present study confirmed that biological tests are indispensable for the reliable assessment of cytotoxic and genotoxic potential of surface and waste waters. There is also a need for chemical analytical characterisation of cytotoxic/genotoxic samples in order to identify and quantify the compounds responsible for the cytotoxicity/genotoxicity.

Keywords: SOS/umuC, Salmonella typhimurium, MTT, comet assay, HepG2, water samples, cytotoxicity, genotoxicity.
\end{abstract}




\section{Introduction}

Water pollution by toxic and genotoxic micropollutants represents one of the most critical problems concerning public health and protection of aquatic ecosystem. Major sources of surface water pollution by a variety of substances are industry, agriculture and domestic households, including municipal wastewaters. Numerous toxic and genotoxic contaminants such as trace metals, polycyclic aromatic hydrocarbons, heterocyclic amines, polychlorinated biphenyls, pesticides, dyes, pharmaceutical and personal care products and many more, can be identified as the components of complex aquatic environmental mixtures [1-3]. These chemicals are released either deliberately or unintentionally into rivers, lakes and seas and can accumulate in sediments. Many genotoxins can also be produced by chemical and biological transformation after the emition into the environment.

Because of the complexity of pollution, standard targeted chemical analyses are limited in their ability to give adequate information regarding toxic or genotoxic potential. The two reasons are: a) toxicological properties of many pollutants are not known and b) chemical analysis cannot predict potential synergistic effects. On the other hand bioassay assessment of polluted samples provides means to evaluate and compare toxic or genotoxic potential of different samples without detailed knowledge of their chemical composition. In this context monitoring for potential genotoxicity is of particular importance as exposure to genotoxic contaminates may be associated with the risk for cancer development.

In the present study genotoxicity and cytotoxicity of environmental water samples was studied by the combination of a bacterial assay SOS/umu test with Salmonella typhimurium TA1535/pSK1002 and with mammalian assays: MTT and comet assay with human hepatoma cell line, HepG2.

\section{Materials and methods}

\subsection{Water samples}

Samples were collected in Slovenia from lakes, rivers, hospital and chemical industry effluents, waste water treatment plant influents and effluents, wells and potable water during the 2004 and 2005 . The samples were stored at $-20^{\circ} \mathrm{C}$ and filtered $(0,22 \mu \mathrm{m}$ pore size $)$ before genotoxicity testing.

\subsection{SOS/umu assay}

The cytotoxic and genotoxic effects of surface and waste water samples were evaluated using SOS/umuC test performed according to Reifferscheid et al. (1991) [4], with minor modifications as described in ISO standards [5]. The tester strain Salmonella typhimurium TA1535/pSK1002 carries the plasmid pSK1002 with $u m u C$ operon fused with the lacZ gene for ß-galactosidase activity. This allows monitoring $u m u C$ induction by measuring $\beta$-galactosidase activity. Water testing was performed with and without S9 metabolic activation. 
Briefly, the overnight culture was diluted 10 times with fresh TGA medium and incubated at $37^{\circ} \mathrm{C}$ for 1.5 hour with shaking until the bacteria reached exponential growth phase. The test was carried out in triplicate on the microtiter plate. The incubation mixture consisted of $180 \mu \mathrm{l}$ un-concentrated water sample, $20 \mu \mathrm{l} 10 \mathrm{x}$ TGA and $70 \mu \mathrm{l}$ bacterial culture or in the case of metabolic activation $180 \mu \mathrm{l}$ un-concentrated water sample, $20 \mu \mathrm{l} 10 \mathrm{x}$ TGA with cofactors and $70 \mu \mathrm{l}$ S9 bacterial culture mixture prepared as described in ISO standard [5]. The microtiter plate was incubated at $37^{\circ} \mathrm{C}$ for 2 hours with shaking. Afterwards the incubation mixture was diluted 10 times with fresh TGA medium. After 2 hour incubation at $37^{\circ} \mathrm{C}$ the growth rate of the biomass was measured $(600 \mathrm{~nm})$ and the induction of the umuC gene was determined by measuring $\beta$-galactosidase activity, using ONPG as a substrate $(420 \mathrm{~nm})$. Biomass was calculated by the formula: $\mathrm{G}=$ (sample $\mathrm{OD}_{600}$ - blank $\mathrm{OD}_{600} /$ control $\mathrm{OD}_{600}$ - blank $\mathrm{OD}_{600}$ ). Growth inhibition of biomass for more than $25 \%$ was considered to be indicative of water samples cytotoxicity. B-galactosidase in relative units was calculated by the formula: $\mathrm{U}=\left(\right.$ sample $\mathrm{OD}_{420}-$ blank $\mathrm{OD}_{420} /$ sample $\mathrm{OD}_{600}-$ blank $\left.\mathrm{OD}_{600}\right)$ and induction ratio (IR) by the formula: $(1 / \mathrm{G}) \times\left(\right.$ sample $\mathrm{OD}_{420}$ - blank $\mathrm{OD}_{420} /$ control $\mathrm{OD}_{420}$ - blank $\left.\mathrm{OD}_{420}\right)$. The induction ratio with a threshold 1,5 was used as a measure of genotoxic potency of water samples. 1-Methyl-3-nitro-1nitrosoguanidine (MNNG; $6 \mu \mathrm{M}$ ) was used as a positive control without and aflatoxin B1 (AFB1; $2 \mu \mathrm{g} / \mathrm{ml}$ ) with metabolic activation.

\subsection{Cell culture}

HepG2 cells (a gift from Dr. Firouz Darroudi, Department of Radiation Genetics and Chemical Mutagenesis, University of Leiden, Netherlands) were grown in William's medium E (Sigma, St. Louis, USA) containing 15\% FBS, 2 mM Lglutamine and $100 \mathrm{U} / \mathrm{ml} \mathrm{pen} / \mathrm{strep}$ at $37^{\circ} \mathrm{C}$ in $5 \% \mathrm{CO}_{2}$. In each experiment the growth medium control and distilled water control were included in order to exclude possible effects of medium dilution. In all the experiments the results of water sample treated cells were compared to the results of distilled water control.

\subsection{Cytotoxicity assay (MTT)}

Cytotoxicity of water samples was determined with 3-(4,5-dimethylthiazol-2-yl)2,5-diphenyltetrazolium bromide (MTT) according to Mosmann (1983) [6], with minor modifications. This assay measures the conversion of MTT to insoluble formazan by dehydrogenase enzymes of the intact mitochondria of living cells. HepG2 cells were seeded at a density of $1 \times 10^{4}$ cells/well into 96-well microtiter plates in five replicates. After 4 hours incubation at $37^{\circ} \mathrm{C}$, growth medium was replaced with fresh medium containing $30 \mathrm{vol} \%$ of water samples and the cells were incubated for 20 hours. After the treatment MTT was added at a final concentration of $0.5 \mathrm{mg} / \mathrm{ml}$ and the cells were further incubated for $3 \mathrm{~h}$ at $37^{\circ} \mathrm{C}$. The medium was removed and the formazan crystals were dissolved in DMSO. The optical density (OD) was measured at $570 \mathrm{~nm}$ (reference filter $690 \mathrm{~nm}$ ) using a spectrofluorimeter (Tecan, Genios). Cell survival (viability) was 
determined by comparing the OD of the wells containing cells treated with water samples to cells exposed to $30 \mathrm{vol} \%$ distilled water in growth medium.

\subsection{Cell treatment and alkaline comet assay}

HepG2 cells were seeded in 12 well cell culture cluster plates (Corning Costar Corporation, New York, USA) and allowed to attach to the plate. After 4 hours the cells were treated with water samples $(5,10,20$ or $30 \mathrm{vol} \%)$ in growth medium for 20 hours. BaP $(40 \mu \mathrm{M})$ was used as a positive control. After the treatment the cells were trypsinized and centrifuged at $800 \mathrm{rpm}$ for $5 \mathrm{~min}$.

The Comet assay was performed according to Sing et al. (1988) [8], with minor modifications. Briefly, $30 \mu \mathrm{l}$ of cell suspension was mixed with $70 \mu 11 \%$ LMP agarose and added to fully frosted slides precoated with $80 \mu \mathrm{l}$ of $1 \%$ NMP agarose. Subsequently, the slides were lysed $(2,5 \mathrm{M} \mathrm{NaCl}, 100 \mathrm{mM}$ EDTA, $10 \mathrm{mM}$ Tris, $1 \%$ Triton $\mathrm{X}-100, \mathrm{pH} 10$ ) for $1 \mathrm{~h}$ at $4{ }^{\circ} \mathrm{C}$, placed into alkaline solution $(300 \mathrm{mM} \mathrm{NaOH}, 1 \mathrm{mM}$ EDTANa $2, \mathrm{pH} 13)$ for $20 \mathrm{~min}$ at $4^{\circ} \mathrm{C}$ to allow DNA unwinding and electrophoresed for $20 \mathrm{~min}$ at $25 \mathrm{~V}(300 \mathrm{~mA})$. Finally, the slides were neutralized in $0,4 \mathrm{M}$ Tris buffer $(\mathrm{pH} 7,5)$ for 15 minutes, stained with $\mathrm{EtBr}$ $(5 \mu \mathrm{g} / \mathrm{ml})$ and analysed using a fluorescence microscope (Nikon, Eclipse 800). Images of 50 randomly selected nuclei per experimental point were analysed with the image analysis software (Comet Assay IV, Perceptive Instruments, UK). The results from three independent experiments are expressed as \% of tail DNA and are shown as Figures in column scatter. The median value is shown as a solid line through the column. One-way analysis of variance (ANOVA, KruskalWallis) was used to analyze the differences between treatments within each experiment. Dunnett's test was used for multiple comparison versus the control; $\mathrm{p}<0,05$ was considered as statistically significant $(*)$.

\section{Results}

Table 1 summarizes the results of genotoxic potential of water samples determined with the SOS/umuC test and results of toxic potential determined with MTT assay with human hepatoma HepG2 cells.

The viability of S.typhimurium TA1535pSK1002 was not affected by water samples, except by one (CIS1) of the two samples from chemical industry. The sample reduced bacterial viability bellow $70 \%$ in the presence of S9 metabolic activation (Table 1). The samples of the effluents from chemical industry (CIS1 and CIS2) were sampled at the same place, but at different time periods.

Cytotoxicity was determined also with metabolically competent human hepatoma cell line (HepG2) using the MTT assay (Table 1). The effluents from hospitals (HS1-5) were not cytotoxic for HepG2 cells, while both effluents from chemical industry (CIS1 and CIS2) reduced cell viability for more than 50\%. Influents to wastewater treatment plants (WWI1-4) were not cytotoxic, however, two (WWE1 and WWE2) of five effluent samples reduced cell viability. Only two (RS1 and RS21) out of twenty-two river samples decreased cell survival, while samples of lake (LS1-6), potable (PS1-6) and well (WS1 and WS2) water were not cytotoxic. 
Table 1: $\quad$ The induction of SOS response in Salmonella typhimurium TA 1535/pSK1002 and the effect on HepG2 cells survival (MTT assay) after treatment with water samples.

\begin{tabular}{|c|c|c|c|c|c|c|c|c|}
\hline \multirow{2}{*}{\multicolumn{2}{|c|}{ SAMPLE }} & \multicolumn{6}{|c|}{ Salmonella typhimurium TA1535/pSK1002 } & \multirow{3}{*}{\begin{tabular}{|l} 
HepG2 \\
MTT \\
Viability \\
$(\%)$ \\
\end{tabular}} \\
\hline & & \multicolumn{3}{|c|}{$\begin{array}{c}\text { Without S9 } \\
\end{array}$} & \multicolumn{3}{|c|}{ With S9 } & \\
\hline & & $\begin{array}{c}\text { Viability } \\
(\%)\end{array}$ & $\mathrm{U} \pm \mathrm{SD}$ & IR & $\begin{array}{c}\text { Viability } \\
(\%)\end{array}$ & $\mathrm{U} \pm \mathrm{SD}$ & IR & \\
\hline \multirow[t]{5}{*}{ HS } & 1 & 112,0 & $0,30 \pm 0,04$ & 1,37 & 121,5 & $\begin{array}{c}0,24 \pm \\
0,02\end{array}$ & 1,02 & 88,10 \\
\hline & 2 & 90,2 & $0,48 \pm 0,03$ & 2,17 & 128,3 & $\begin{array}{c}0,38 \pm \\
0,06\end{array}$ & 1,61 & 130,61 \\
\hline & 3 & 100,6 & $0,27 \pm 0,03$ & 0,88 & 116,9 & $\begin{array}{c}0,25 \pm \\
0,02\end{array}$ & 1,03 & 90,90 \\
\hline & 4 & 103,1 & $0,47 \pm 0,07$ & 1,51 & 121,2 & $\begin{array}{c}0,35 \pm \\
0,02\end{array}$ & 1,43 & 101,14 \\
\hline & 5 & 115,6 & $0,40 \pm 0,04$ & 1,27 & 169,1 & $\begin{array}{c}0,30 \pm \\
0,03\end{array}$ & 1,32 & 91,90 \\
\hline \multirow[t]{2}{*}{ CIS } & 1 & 79,8 & $1,18 \pm 0,27$ & 5,34 & 66,7 & $\begin{array}{c}2,44 \pm \\
0,54\end{array}$ & 10,25 & 46,11 \\
\hline & 2 & 82,0 & $0,54 \pm 0,13$ & 1,69 & 141,1 & $\begin{array}{c}0,49 \pm \\
0,03 \\
\end{array}$ & 1,96 & 52,62 \\
\hline \multirow[t]{4}{*}{ WWI } & 1 & 126,9 & $0,28 \pm 0,02$ & 1,28 & 149,2 & $\begin{array}{c}0,27 \pm \\
0,03\end{array}$ & 1,13 & 98,05 \\
\hline & 2 & 114,3 & $0,33 \pm 0,05$ & 1,04 & 147,6 & $\begin{array}{c}0,24 \pm \\
0,04\end{array}$ & 0,99 & 95,27 \\
\hline & 3 & 111,4 & $0,30 \pm 0,02$ & 0,95 & 158,5 & $\begin{array}{c}0,26 \pm \\
0,03\end{array}$ & 1,07 & 82,28 \\
\hline & 4 & 116,9 & $0,25 \pm 0,01$ & 1,14 & 119,4 & $\begin{array}{c}0,25 \pm \\
0,01\end{array}$ & 1,04 & 81,35 \\
\hline \multirow[t]{4}{*}{ WWE } & 1 & 110,8 & $0,33 \pm 0,04$ & 1,05 & 150,0 & $\begin{array}{c}0,28 \pm \\
0,01\end{array}$ & 1,15 & 71,21 \\
\hline & 2 & 112,4 & $0,29 \pm 0,02$ & 1,28 & 120,4 & $\begin{array}{c}0,33 \pm \\
0,05\end{array}$ & 1,38 & 66,60 \\
\hline & 3 & 109,7 & $0,37 \pm 0,04$ & 1,19 & 149,8 & $\begin{array}{c}0,27 \pm \\
0,01\end{array}$ & 1,11 & 105,14 \\
\hline & 4 & 114,7 & $0,52 \pm 0,26$ & 2,35 & 125,9 & $\begin{array}{c}0,26 \pm \\
0,02\end{array}$ & 1,10 & 84,27 \\
\hline \multirow[t]{9}{*}{$\mathrm{RS}$} & 1 & 108,4 & $0,30 \pm 0,03$ & 0,96 & 112,1 & $\begin{array}{c}0,26 \pm \\
0,04\end{array}$ & 1,08 & 70,72 \\
\hline & 2 & 101,6 & $0,30 \pm 0,08$ & 1,37 & 120,0 & $\begin{array}{c}0,24 \pm \\
0,02\end{array}$ & 1,02 & 82,28 \\
\hline & 3 & 106,0 & $0,35 \pm 0,05$ & 1,12 & 110,5 & $\begin{array}{c}0,27 \pm \\
0,04\end{array}$ & 1,09 & 97,92 \\
\hline & 4 & 106,0 & $0,25 \pm 0,05$ & 0,80 & 144,8 & $\begin{array}{c}0,33 \pm \\
0,01\end{array}$ & 1,45 & 89,36 \\
\hline & 5 & 113,3 & $0,35 \pm 0,12$ & 1,59 & 110,8 & $\begin{array}{c}0,27 \pm \\
0,03\end{array}$ & 1,15 & 106,82 \\
\hline & 6 & 104,9 & $0,31 \pm 0,05$ & 1,01 & 143,7 & $\begin{array}{c}0,35 \pm \\
0,02\end{array}$ & 1,52 & 91,83 \\
\hline & 7 & 114,5 & $0,36 \pm 0,00$ & 1,61 & 134,7 & $\begin{array}{c}0,31 \pm \\
0,07\end{array}$ & 1,33 & 102,89 \\
\hline & 8 & 100,0 & $0,30 \pm 0,03$ & 0,97 & 121,0 & $\begin{array}{c}0,25 \pm \\
0,02\end{array}$ & 1,03 & 108,73 \\
\hline & 9 & 96,2 & $0,27 \pm 0,03$ & 0,85 & 113,5 & $\begin{array}{c}0,31 \pm \\
0,02\end{array}$ & 1,25 & 109,56 \\
\hline
\end{tabular}


Table 1: Continued.

\begin{tabular}{|c|c|c|c|c|c|c|c|c|}
\hline \multirow{2}{*}{\multicolumn{2}{|c|}{ SAMPLE }} & \multicolumn{6}{|c|}{ Salmonella typhimurium TA1535/pSK1002 } & \multirow{3}{*}{$\begin{array}{l}\text { HepG2 } \\
\text { MTT } \\
\text { Viability } \\
(\%) \\
\end{array}$} \\
\hline & & \multicolumn{3}{|c|}{$\begin{array}{c}\text { Without S9 } \\
\end{array}$} & \multicolumn{3}{|c|}{ With S9 } & \\
\hline & & $\begin{array}{c}\text { Viability } \\
(\%)\end{array}$ & $\mathrm{U} \pm \mathrm{SD}$ & IR & $\begin{array}{c}\text { Viability } \\
\text { (\%) }\end{array}$ & $\mathrm{U} \pm \mathrm{SD}$ & IR & \\
\hline & 10 & 96,4 & $0,26 \pm 0,05$ & 0,85 & 119,0 & $\begin{array}{c}0,21 \pm \\
0,04\end{array}$ & 0,88 & 102,11 \\
\hline & 11 & 100,0 & $0,32 \pm 0,07$ & 1,02 & 120,8 & $\begin{array}{c}0,29 \pm \\
0,05\end{array}$ & 1,19 & 111,44 \\
\hline & 12 & 105,3 & $0,27 \pm 0,01$ & 1,21 & 120,1 & $\begin{array}{c}0,27 \pm \\
0,02\end{array}$ & 1,15 & 79,20 \\
\hline & 13 & 105,6 & $0,33 \pm 0,05$ & 1,07 & 132,5 & $\begin{array}{c}0,28 \pm \\
0,00\end{array}$ & 1,15 & 117,02 \\
\hline & 14 & 103,9 & $0,24 \pm 0,02$ & 1,08 & 115,4 & $\begin{array}{c}0,24 \pm \\
0,01\end{array}$ & 1,03 & 97,53 \\
\hline & 15 & 103,9 & $0,34 \pm 0,01$ & 1,08 & 119,4 & $\begin{array}{c}0,27 \pm \\
0,04\end{array}$ & 1,11 & 82,79 \\
\hline & 16 & 107,4 & $0,28 \pm 0,11$ & 0,92 & 113,9 & $\begin{array}{c}0,27 \pm \\
0,05\end{array}$ & 1,10 & 92,47 \\
\hline & 17 & 105,7 & $0,30 \pm 0,00$ & 0,97 & 119,4 & $\begin{array}{c}0,27 \pm \\
0,02\end{array}$ & 1,19 & 96,96 \\
\hline & 18 & 93,2 & $0,36 \pm 0,03$ & 1,44 & 114,1 & $\begin{array}{c}0,23 \pm \\
0,04\end{array}$ & 0,95 & 98,79 \\
\hline & 19 & 115,0 & $0,34 \pm 0,01$ & 1,52 & 141,0 & $\begin{array}{c}0,36 \pm \\
0,04\end{array}$ & 1,55 & 97,60 \\
\hline & 20 & 103,2 & $0,29 \pm 0,07$ & 0,94 & 127,3 & $\begin{array}{c}0,28 \pm \\
0,02\end{array}$ & 1,23 & 93,70 \\
\hline & 21 & 106,7 & $0,38 \pm 0,04$ & 1,21 & 115,3 & $\begin{array}{c}0,23 \pm \\
0,03\end{array}$ & 0,95 & 74,42 \\
\hline & 22 & 102,5 & $0,33 \pm 0,01$ & 1,06 & 140,3 & $\begin{array}{c}0,30 \pm \\
0,03\end{array}$ & 1,31 & 100,11 \\
\hline \multirow[t]{6}{*}{ LS } & 1 & 110,4 & $0,30 \pm 0,03$ & 1,35 & 147,1 & $\begin{array}{c}0,30 \pm \\
0,02\end{array}$ & 1,33 & 85,23 \\
\hline & 2 & 103,5 & $0,31 \pm 0,03$ & 1,38 & 124,1 & $\begin{array}{c}0,38 \pm \\
0,03\end{array}$ & 1,64 & 107,10 \\
\hline & 3 & 101,4 & $0,31 \pm 0,03$ & 1,40 & 141,9 & $\begin{array}{c}0,33 \pm \\
0,05\end{array}$ & 1,44 & 93,01 \\
\hline & 4 & 102,7 & $0,28 \pm 0,03$ & 1,27 & 143,9 & $\begin{array}{c}0,33 \pm \\
0,03\end{array}$ & 1,43 & 102,17 \\
\hline & 5 & 103,3 & $0,45 \pm 0,19$ & 2,00 & 151,4 & $\begin{array}{c}0,29 \pm \\
0,03\end{array}$ & 1,28 & 99,06 \\
\hline & 6 & 101,2 & $0,34 \pm 0,04$ & 1,51 & 125,9 & $\begin{array}{c}0,35 \pm \\
0,04 \\
\end{array}$ & 1,53 & 95,62 \\
\hline \multirow[t]{6}{*}{ PS } & 1 & 88,1 & $0,30 \pm 0,07$ & 1,21 & 129,8 & $\begin{array}{c}0,25 \pm \\
0,02\end{array}$ & 1,05 & 98,80 \\
\hline & 2 & 96,2 & $0,27 \pm 0,02$ & 1,08 & 120,2 & $\begin{array}{c}0,21 \pm \\
0,06\end{array}$ & 0,84 & 103,79 \\
\hline & 3 & 107,3 & $0,39 \pm 0,08$ & 1,23 & 116,7 & $\begin{array}{c}0,29 \pm \\
0,04\end{array}$ & 1,19 & 94,79 \\
\hline & 4 & 110,0 & $0,28 \pm 0,07$ & 0,91 & 115,7 & $\begin{array}{c}0,27 \pm \\
0,07\end{array}$ & 1,09 & 107,25 \\
\hline & 5 & 108,4 & $0,25 \pm 0,04$ & 0,82 & 116,5 & $\begin{array}{c}0,28 \pm \\
0,04\end{array}$ & 1,13 & 109,76 \\
\hline & 6 & 89,6 & $0,39 \pm 0,05$ & 1,57 & 123,2 & $\begin{array}{c}0,23 \pm \\
0,01\end{array}$ & 0,95 & 105,24 \\
\hline
\end{tabular}


Table 1: Continued.

\begin{tabular}{|c|c|c|c|c|c|c|c|c|}
\hline \multirow{2}{*}{\multicolumn{2}{|c|}{ SAMPLE }} & \multicolumn{6}{|c|}{ Salmonella typhimurium TA1535/pSK1002 } & \multirow{3}{*}{$\begin{array}{l}\text { HepG2 } \\
\text { MTT } \\
\begin{array}{c}\text { Viability } \\
(\%)\end{array}\end{array}$} \\
\hline & & \multicolumn{3}{|c|}{ Without S9 } & \multicolumn{3}{|c|}{ With S9 } & \\
\hline & & $\begin{array}{c}\text { Viability } \\
(\%)\end{array}$ & $\mathrm{U} \pm \mathrm{SD}$ & IR & $\begin{array}{c}\text { Viability } \\
(\%)\end{array}$ & $\mathrm{U} \pm \mathrm{SD}$ & IR & \\
\hline \multirow[t]{2}{*}{ WS } & 1 & 81,5 & $0,28 \pm 0,03$ & 1,11 & 119,4 & $\begin{array}{c}0,25 \pm \\
0,08\end{array}$ & 1,05 & 105,21 \\
\hline & 2 & 91,4 & $0,28 \pm 0,02$ & 1,12 & 119,6 & $\begin{array}{c}0,25 \pm \\
0,03\end{array}$ & 1,02 & 85,59 \\
\hline \multicolumn{2}{|c|}{ MNNG } & 92,9 & & 2,48 & 1 & / & / & / \\
\hline \multicolumn{2}{|c|}{ AFB1 } & 1 & 1 & 1 & 100,9 & & 2,93 & I \\
\hline
\end{tabular}

HS-hospital sample; CIS-chemical industry sample; WWI-waste water influent; WWE- waste water effluent; RS-river sample; LS-lake sample; PS-potable water sample; WS-well sample. Positive results are shown in bold type.

The genotoxicity testing results showed for most of the samples that induction ratio (IR) of $\beta$-galactosidase activity between exposed and control bacteria was around 1 indicating that these samples did not induce umuC system. However, the two hospital effluents (HS2 and HS4) and both samples from chemical industry (CIS1 and CIS2) induced genotoxic responses. The IR in bacteria exposed to sample CIS2 was 5 and 10 in the absence and presence of S9, respectively. Samples of wastewater influents were not genotoxic, while one sample of wastewater effluent (WWE4) induced IR of 2.3. Four (RS5, 6, 7 and 19) out of twenty-two river samples and three (LS2, 5 and 6) out of six lake samples induced IR above 1,5. Interestingly also one potable water sample (PS6) showed genotoxic effect, while no well water induced genotoxic response.

In order to confirm the genotoxic activity of water samples in mammalian cells seven samples were selected and tested for their genotoxic potential using the comet assay. The HepG2 cells were exposed to different concentrations of water samples $(0,10,20$ and $30 \mathrm{vol} \%)$ for 20 hours.

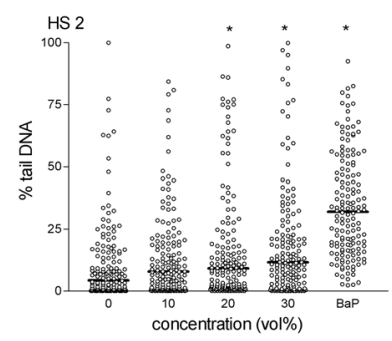

Figure 1: The level of DNA damage induced by effluent from hospital (HS2).

The comet assay results showed that hospital sample (HS 2) which was positive in the SOS/uтиC assay also increased the amount of single strand breaks in HepG2 cells dose dependently (Figure 1).

DNA damage of HepG2 cells was detected after exposure of cells to $20 \mathrm{vol} \%$ of wastewater influent (WWI 4) sample, while the effluent from wastewater 
treatment plant (WWE 4) did not induce significant increase of DNA damage, although this sample was positive in SOS/umuC test (Figure 2).

Both samples of effluents from chemical industry (CIS1 and CIS2) (Figure 3) were tested at lower concentrations than other samples $(0,5,10$ and 20 vol \%) due to their cytotoxicity for HepG2 cells. Both samples were shown to be highly genotoxic in SOS/umuC assay and in mammalian cell test system.

We also determined the genotoxic potential of two surface water samples (Figure 4). Lake water sample LS6, which was positive in SOS/umu test showed slight genotoxic activity only at the highest concentration used (30 vol \%), while river water sample (RS14), which was negative in the SOS/umu test did not induce DNA strand breaks.
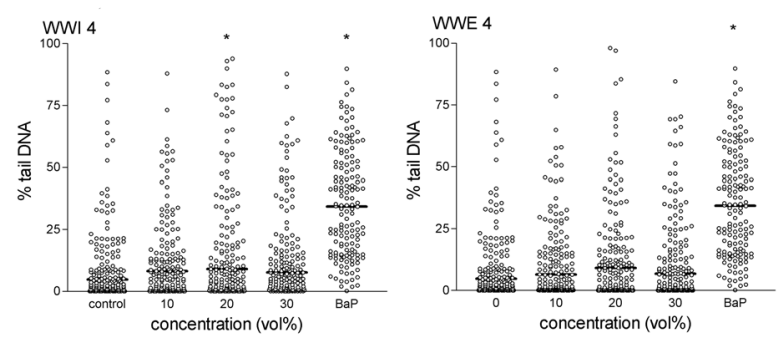

Figure 2: The level of DNA damage induced by wastewater treatment plant influent (WWI 4) and effluent (WWE 4).
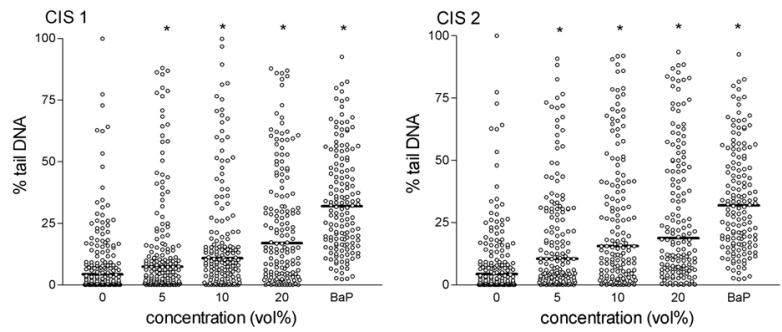

Figure 3: The level of DNA damage induced by chemical industry effluent (CIS 1 and CIS 2).
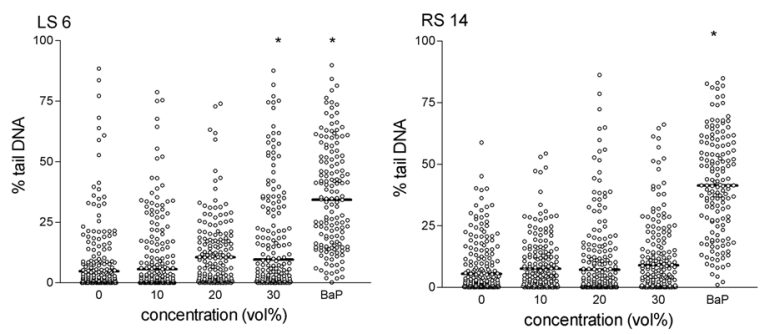

Figure 4: The level of DNA damage induced by lake (LS6) and river (RS14) water samples. 


\section{Discussion}

Surface waters such as lakes and rivers can be used as a source of drinking water, in agricultural and recreational activities as well as for the industrial purposes. As these waters can be potentially polluted with unknown compounds, this can have adverse effects on humans and indigenous biota. Indeed, in the past years a variety of bioassays were used to show that industrial effluents and wastes as well as environmental surface waters can have mutagenic activity (reviewed in [2]).

In the present study genotoxicity and cytotoxicity of surface and waste water samples collected in Slovenia were studied by a combination of SOS/uтиC on Salmonella typhimurium TA1535/pSK1002 with and without metabolic activation and MTT and the comet assay with human hepatoma HepG2 cells. Our results showed that in the SOS/umuC test out of 51 water samples $11(21 \%)$ were genotoxic without and $7(13 \%)$ with metabolic activation. One sample was toxic for prokaryotic organisms, while 7 samples reduced viability of eukaryotic cells. As already described in other studies [1,9], our experiments confirmed that the use of metabolic activation did not increase the sensitivity of Salmonella tester strain. This indicates that putative genotoxins in both surface and waste waters are primarily direct-acting.

Genotoxic compounds present in mixed municipal wastewaters can include sanitary wastes, pesticides used in agriculture, runoffs from roadways, commercial and industrial areas, hospitals and research institutions [1].

Hospitals represent an incontestable release source of many pharmaceutical drugs, DNA damaging agents and their metabolic products. Some of the substances found in hospital wastewaters are genotoxic and are suspected to be a possible risk factor for increased occurrence of the cancers observed during the last decades [8]. Our study showed that hospital effluents showed genotoxic effects in both assays used in this study. The data confirmed that effluents from hospitals represent a serious threat for environment and human health.

White and Rasmussen [1] presented that municipal wastewaters rank low in genotoxic potency, however, they can achieve loading values that are several orders of magnitude greater that wastes from industries. For this reason domestic wastewaters can constitute great genotoxic hazard to aquatic environment and biota. Wastewater treatment plant influent and effluent samples tested in the present study showed little or no cytotoxic/genotoxic activity. On the contrary, the chemical industry effluent water samples had high genotoxic potency in both test systems. However, we should bear in mind that these effluents are prior to release into the environment treated in the municipal wastewater treatment plant.

We showed that one third of lake and one fifth of river samples increased genotoxic response in bacteria. The data obtained with the comet assay confirmed the positive result in lake and the negative result in river sample. Apart from domestic and sanitary wastes, urban runoffs, pharmaceutical and chemical compounds, natural aquatic environment can be polluted also with compounds such as organic UV filters and antimicrobial agents, which are used in personal care products and cosmetics. These substances can enter water 
indirectly through wastewater treatment plants or directly from recreational activities such as swimming and bathing in lakes and rivers. Once released in the aquatic environment they can be transformed by photooxidation to potentially more harmful compounds. Chemical analysis of lake and river water samples revealed the presence of compounds originating from personal care products (UV filters and antimicrobial agents). However, personal care products active ingredients represent only one group of possible contaminants in water samples. Further chemical characterisation of samples is needed before coming to conclusions.

With the SOS/umu assay we detected genotoxicity of one sample of potable water. Genotoxicity of potable water is often the consequence of the formation of disinfection by-products of which many are known to be genotoxic and also carcinogenic. In the case of chronic exposure of potentially genotoxic drinking water this can pose a serious health risk of unknown magnitude.

The combination of SOS/umuC test with prokaryotic organism and MTT and comet assay with mammalian cells appeared to be appropriate and sufficiently sensitive assays to monitor genotoxicity of natural surface and waste waters. This study again confirmed that bioassays can be an integral tool for identification of toxicity/genotoxicity of the complex mixtures and to monitor effluents and their products that are formed during degradation as well as to provide data for comparative risk assessment.

\section{References}

[1] White, P.A. \& Rasmussen, J.B. The genotoxic hazards of domestic wastes in surface waters. Mutation Research 410, 223-236, 1998.

[2] Ohe, T., Watanabe, T. \& Wakabayashi, K. Mutagens in surface waters: a review. Mutation Research 567, 109-149, 2004.

[3] Kosjek, T, Heath, E. \& Krbavčič, A. Determination of non-steroidal antiinflammatory drug (NSAIDs) residues in water samples. Environment International, 31, 5, 679-685, 2005.

[4] Reifferscheid, G., Heil, J., Oda, Y. \& Zahn, R.K. A microplate version of the SOS/umu-test for rapid detection of genotoxins and genotoxic potentials of environmental samples. Mutation Research 253, 215-222, 1991.

[5] ISO/CD 13829: Water quality- Determination of the genotoxicity of water and waste water using umu-test. 2000.

[6] Mosmann, T. Rapid colorimetric assay for cellular growth and survival: application to proliferation and cytotoxicity assays. Journal of Immunological Methods, 65, 16, 55-63, 1983.

[7] Singh, N.P., McCoy, M.T., Tice, R.R. \& Schneider, E.L. A simple technique for quantitation of low levels of DNA damage in individual cells. Experimental Cell Research, 175, 1, 184-191, 1988.

[8] Jolibois, B. \& Guerbet, M. Hospital wastewater genotoxicity. Annals of Occupational Hygiene 50(2), 189-196, 2006. 